(c) American Dairy Science Association, 2007.

\title{
Interventions After Artificial Insemination: Conception Rates, Pregnancy Survival, and Ovarian Responses to Gonadotropin-Releasing Hormone, Human Chorionic Gonadotropin, and Progesterone ${ }^{1}$
}

\author{
J. S. Stevenson, ${ }^{\star 2}$ M. A. Portaluppi, ${ }^{\star}$ D. E. Tenhouse, ${ }^{\star}$ A. Lloyd, ${ }^{\star}$ D. R. Eborn, ${ }^{\star}$ \\ S. Kacuba, $†$ and J. M. DeJarnette \\ *Department of Animal Sciences and Industry, Kansas State University, Manhattan 66506-0201 \\ †East Central Select Sires, Waupon, WI 53916 \\ ¥Select Sires, Plain City, OH 43064-0143
}

\begin{abstract}
We hypothesized that increasing concentrations of progesterone ( $\mathrm{P} 4)$ after artificial insemination would increase fertility. Our objective was to assess changes in ovarian structures, incidence of ovulation, and change in serum $\mathrm{P} 4$ in response to $\mathrm{GnRH}$, human chorionic gonadotropin (hCG), or exogenous $\mathrm{P} 4$ (controlled internal drug release; CIDR insert) treatment beginning 4 to $9 \mathrm{~d}$ after artificial insemination ( $\mathrm{d} 0$ ) and again $7 \mathrm{~d}$ later (experiment 1). Blood was collected from 753 cows in 3 herds on $\mathrm{d} 0$ and 7 . Ovaries of 162 cows were scanned and mapped to confirm the presence of a corpus luteum (CL), and cows were assigned randomly to serve as controls $(\mathrm{n}=41)$ or to receive a CIDR insert for $7 \mathrm{~d}(\mathrm{n}=$ 41), $100 \mu \mathrm{g}$ of GnRH ( $\mathrm{n}=40$ ), or 3,300 IU of hCG ( $\mathrm{n}=$ 40). More cows were induced to ovulate in response to GnRH (60\%) and hCG (78\%) compared with controls (2.4\%). Compared with controls, cows treated with GnRH or hCG had more induced CL (d 7) and more total CL (d 7), but serum P4 was increased only in response to hCG. Largest follicle diameters on $\mathrm{d} 7$ were less after GnRH and hCG, but total follicular volume on $d 7$ was reduced by $\mathrm{GnRH}, \mathrm{hCG}$, and CIDR, compared with that of controls. Volume of the original luteal structures was increased by hCG but tended to be reduced by CIDR and GnRH compared with luteal volume in controls. Total CL volume was increased by hCG, but reduced by CIDR, compared with CL volume of controls. Conception rates and pregnancy survival were assessed in response to the same treatments described in experiment 1 : controls $(\mathrm{n}=$ 708), CIDR ( $\mathrm{n}=711), \mathrm{GnRH}(\mathrm{n}=719)$, and hCG ( $\mathrm{n}=$ 714). Tendencies for interactions of treatment $\times$ herd and treatment $\times$ lactation group were detected, but no 3 -way interactions were found. Treatment with hCG in-
\end{abstract}

Received June 19, 2006.

Accepted August 29, 2006.

${ }^{1}$ Contribution number 06-332-J from the Kansas Agricultural Experiment Station, Manhattan.

${ }^{2}$ Corresponding author: jss@k-state.edu creased conception rates in second-lactation cows. The CIDR tended to increase, and hCG increased, conception rates in 2 herds, whereas the CIDR decreased conception rates in 1 herd. Pregnancy survival was reduced by GnRH compared with that in controls. We concluded that GnRH and hCG effectively induced ovulation, and increased number of CL, but only increased serum P4 in hCG-treated cows. Further, treatment with the CIDR or hCG increased conception rates but only in some herds.

Key words: gonadotropin-releasing hormone, human chorionic gonadotropin, pregnancy survival, progesterone

\section{INTRODUCTION}

Conception failure is coincident with less than normal concentrations of progesterone (P4) as early as d 6 after insemination (Thatcher et al., 2001). In general, blood concentrations of $\mathrm{P} 4$ rise earlier and achieve greater concentrations in pregnant than in nonpregnant cows (Thatcher et al., 2001). Embryo development is associated with concentrations of P4 and the ability of the conceptus to secrete the antiluteolytic hormone, interferon-tau (Mann et al., 1999). Exogenous P4 has been shown to stimulate embryo development (Thatcher et al., 1994). A number of treatments could be used to increase peripheral concentrations of $\mathrm{P} 4$ after $\mathrm{AI}$, including those that increase endogenous function of the existing corpus luteum (CL), induce accessory CL, or supplement progestin or $\mathrm{P} 4$ directly.

In recent years, human chorionic gonadotropin (hCG) has been evaluated for its ability to improve fertility of cows and heifers through altered ovarian function. Human chorionic gonadotropin has activity similar to $\mathrm{LH}$, is able to bind to tissue LH receptors, and mimics effects of LH by causing small luteal cells to increase P4 synthesis. When given early in the estrous cycle ( $\mathrm{d} 3$ to 5 ; d 0 = estrus), hCG can alter proportions of small and large luteal cells, thus potentially changing total $\mathrm{P} 4$ production by the CL, because approximately $80 \%$ of 
luteal P4 is derived from large luteal cells (Niswender et al., 2000). When administered during the midluteal phase (d 10 to 15), hCG alters duration of the estrous cycle (Eduvie and Seguin, 1982; Howard and Britt, 1990) and enhances endogenous concentrations of P4 (Schmitt et al., 1996; Santos et al., 2001) through luteotropic effects on the existing CL or by increasing the incidence of ovulation and accessory CL formation (Rajamahendran and Sianangama, 1992; Santos et al., 2001). In addition, luteal phase treatment with hCG after AI increased conception rates (Breuel et al., 1989; Santos et al., 2001).

Studies that administered exogenous progestins during the luteal phase after AI by applying P4-releasing intravaginal devices (PRID) for $7 \mathrm{~d}$ produced inconsistent effects on conception rates (Robinson et al., 1989; Stevenson and Mee, 1991). Concentrations of P4 in the former study were increased when cows were treated with PRID for $7 \mathrm{~d}$ between $\mathrm{d} 5$ and 12 but not when treated between d 12 and 19 after AI. Conception rates of cows were improved, however, after treatments during either period of the luteal phase (Robinson et al., 1989). No increase in conception rates was detected when intravaginal controlled internal drug release (CIDR) inserts were applied midcycle or later. In contrast, when treatments were initiated before midcycle, conception rates were improved for cows treated with CIDR inserts for 6 or $12 \mathrm{~d}$, beginning 4 to $9 \mathrm{~d}$ after AI compared with controls (Macmillan and Peterson, 1993). The treatment that most consistently improved conception rates in that study was a 6- or 12-d CIDR insert beginning on 6 to $8 \mathrm{~d}$ after AI. Furthermore, a meta-analysis of $17 \mathrm{P} 4$ supplementation studies indicated treatment during the first week after AI enhances conception rates but has no effect when administered during the second or third weeks after AI (Mann and Lamming, 1999). Similar CIDR treatments administered to cows with or without an active CL increased peripheral concentrations of P4 in suckled beef cattle by 0.5 to $1 \mathrm{ng} / \mathrm{mL}$ (Stevenson et al., 2003) or only slightly in lactating dairy cattle (Stevenson et al., 2006).

Inducing accessory $\mathrm{CL}$ with $\mathrm{GnRH}$ or its agonists is well documented and forms the basis for the first $\mathrm{GnRH}$ injection of the Ovsynch protocol (Pursley et al., 1998). Subsequent work demonstrated that incidence of ovulation was greatest when GnRH was injected between d 5 and 12 of the estrous cycle (Vasconcelos et al., 1999). When injected on d 5 or 6 , a GnRH agonist ( $8 \mu \mathrm{g}$ of Buserelin) was equally effective as 3,000 IU of hCG for inducing accessory CL, but the subsequent increase in concentrations of $\mathrm{P} 4$ was greater in hCG-treated heifers (Schmitt et al., 1996).

We hypothesized that increasing or supplementing endogenous concentrations of P4 in lactating dairy cattle early after AI may spare embryonic loss and improve overall conception rates. Our overall objective was to investigate the effect of supplemental blood $\mathrm{P} 4$ and exogenous GnRH and hCG on follicular development, incidence of ovulation, serum $\mathrm{P} 4$, conception rate, and pregnancy survival.

\section{MATERIALS AND METHODS}

\section{Experimental Approach}

Lactating Holstein cows were blocked by DIM and lactation number ( 1 vs. $2+$ ) and assigned randomly to 4 treatments: 1) insert a new CIDR (Eazi-Breed CIDR insert containing $1.38 \mathrm{~g}$ of P4; Pfizer Animal Health, New York, NY) for $7 \mathrm{~d}$, beginning between 4 and $9 \mathrm{~d}$ after AI; 2) 3,300 IU of hCG, i.m. (Chorulon; Intervet, Millsboro, NJ) once between 4 and 9 d after AI; 3) 100 $\mu \mathrm{g}$ of GnRH, i.m. (Fertagyl; Intervet) once between d 4 and 9 after AI; and 4) untreated controls. Body condition scores $(1=$ thin and $5=$ fat $)$ were assessed at the time of treatment.

\section{Experiment 1}

The purpose of experiment 1 was to assess ovarian responses to GnRH, hCG, and exogenous P4 (CIDR insert). Ovaries of 162 lactating Holstein cows housed at the Kansas State University Dairy Teaching and Research Center were scanned by using transrectal ultrasonography $(5 \mathrm{mHz}$ transrectal probe, Aloka $500 \mathrm{~V}$, Corimetrics, Wallingford, CT). Ovarian structures were mapped and sized on the day of treatment and $7 \mathrm{~d}$ later. The following measurements and subsequent calculations were made: 1 ) difference in the number of follicles $\geq 5 \mathrm{~mm}$ in diameter at treatment ( $\mathrm{d} 0$ ) and $7 \mathrm{~d}$ later; 2 ) size of the largest follicle $7 \mathrm{~d}$ after treatment; 3 ) percentage of cows having induced ovulation; 4) total number of CL 7 d after treatment; 5) total number of induced CL; 6) increased diameter and volume of the original CL assessed on $7 \mathrm{~d}$ after treatment; 7) size of follicles that ovulated; 8) total follicular volume $7 \mathrm{~d}$ after treatment; and 9) total luteal volume $7 \mathrm{~d}$ after treatment. Follicles and CL were assumed to be spherical in shape. Diameter was assessed by averaging the largest cross-sectional width and height. Volume of follicles and CL were calculated as follows:

$$
\begin{gathered}
\text { Radius }=(\mathrm{W} / 2+\mathrm{H} / 2) / 2 \text {, where } \mathrm{W}=\text { largest width } \\
\text { and } \mathrm{H}=\text { largest height of structure; } \\
\text { Volume }=4 / 3 \times \mathrm{R}^{3} \times \pi, \\
\text { where } \mathrm{R}=\text { radius and } \pi=3.14159 .
\end{gathered}
$$


Table 1. Herd characteristics for lactating dairy cows enrolled in 2 experiments

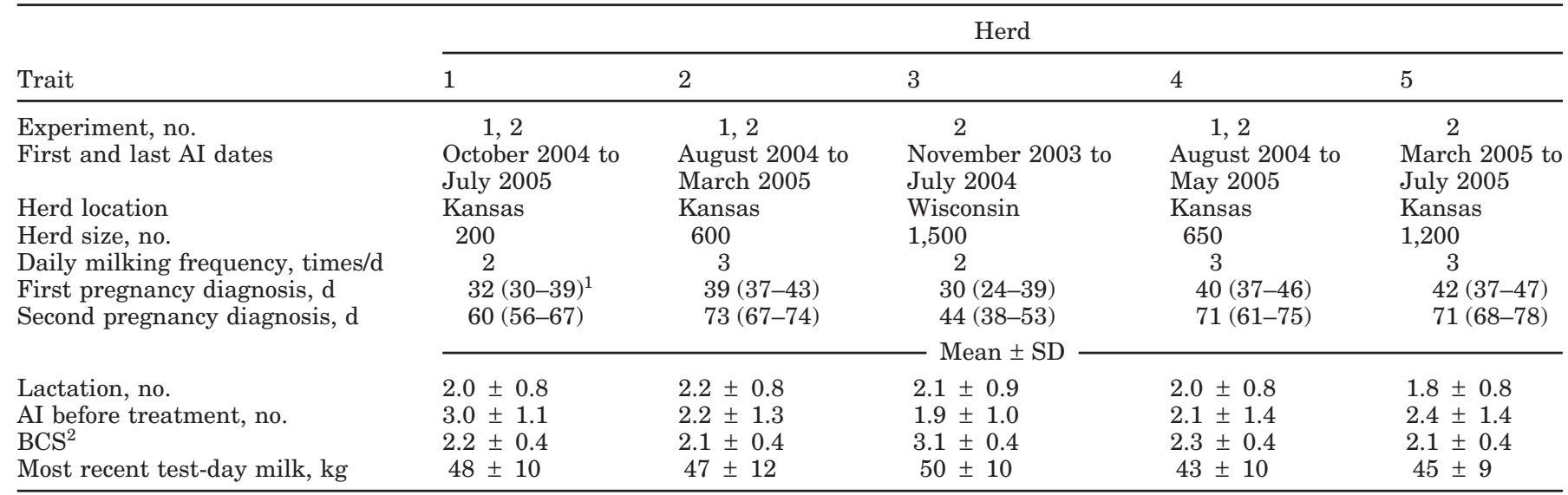

${ }^{1}$ Range in days after AI.

${ }^{2}$ Assessed at treatment $(1=$ thin and $5=$ fat $)$.

For all CL in which fluid cavities were detected, volume of the cavity was calculated and subtracted from the volume of the entire CL.

Blood was collected at the initiation of treatments and $7 \mathrm{~d}$ later to measure treatment effects on serum concentrations of P4. Cows located in the Kansas State University dairy, and at 2 commercial dairy farms in which experiment 2 was being conducted, had blood samples collected as described relative to treatments (Table 1). Blood serum concentrations of $\mathrm{P} 4$ were determined by radioimmunoassay (Skaggs et al., 1986) for samples collected at treatment and $7 \mathrm{~d}$ later. Both samples collected from each cow were included in the same assay. Intraand interassay coefficients of variation for 11 assays were 7.7 and $9.8 \%$, respectively, for a pooled sample that averaged $3.9 \pm 0.07 \mathrm{ng} / \mathrm{mL}$.

All variables were analyzed by using ANOVA (procedure GLM; SAS Inst. Inc., Cary, NC) with a model consisting of treatment $(n=4)$, lactation number $(1,2$, or $3+)$, interaction of treatment $\times$ lactation number, plus covariables including BCS, most recent test-day milk, and DIM at onset of treatment. A priori contrasts were made for each treatment vs. the control. Partial correlations between original follicle sizes and subsequent luteal sizes of those follicles that ovulated, total luteal volume, and serum P4 were calculated by using the MANOVA option in procedure GLM (SAS Inst. Inc.).

Increases in concentrations of $\mathrm{P} 4$ from the onset of treatment to $7 \mathrm{~d}$ later ( 7 minus d 0) were compared by using ANOVA (procedure GLM; SAS Inst. Inc.). The model consisted of treatment $(n=4)$, herd $(n=3)$, lactation number $(1,2$, or $3+)$, interactions of treatment $\times$ herd and treatment $\times$ lactation number, plus covariables including most recent test-day milk and BCS. A priori contrasts were made for each treatment vs. the control.

\section{Experiment 2}

The purpose of experiment 2 was to assess effects of treatments on conception rates and pregnancy survival. A total of 2,852 lactating Holstein cows were treated in the Kansas State University herd and at 4 commercial dairy locations (Table 1). Projected sample sizes were based on being able to detect a 5\% difference in conception rate with $85 \%$ power. Pregnancy was diagnosed by using transrectal ultrasonography or transrectal palpation (Table 1), and pregnancy was reconfirmed in all pregnant cows 14 to $30 \mathrm{~d}$ later to monitor pregnancy survival.

Conception rates were calculated based on the number of pregnant cows at each diagnosis divided by the number of cows previously inseminated and treated. Resulting pregnancy survival between the first and subsequent pregnancy diagnosis was calculated. Conception rates and pregnancy survival were analyzed by using logistic regression (procedure GENMOD; SAS Inst. Inc.) with a model consisting of treatment $(\mathrm{n}=4)$, lactation number $(1,2$, or $3+)$, herd ( $=5)$, 2-way interactions of treatment with herd and lactation number, month of treatment nested within herd, day after AI at onset of treatment nested within herd, and most recent test-day milk, DIM, and BCS (covariables). A priori contrasts were made for each treatment vs. the control. When interactions of treatment $\times$ lactation number $(1,2$, or $3+)$ or treatment $\times$ herd occurred, individual treatment comparisons were made with the control by $\chi^{2}$ within lactation number or herd, respectively.

\section{RESULTS}

Characteristics of herds and cows enrolled in the 2 experiments are summarized in Table 1. Retention of 
Table 2. Ovarian characteristics before $(\mathrm{d} 0)$ and after $(\mathrm{d} 7)$ postinsemination treatments of progesterone [(P4) controlled internal drug release (CIDR insert)], GnRH, and human chorionic gonadotropin (hCG) in lactating dairy cows (experiment 1)

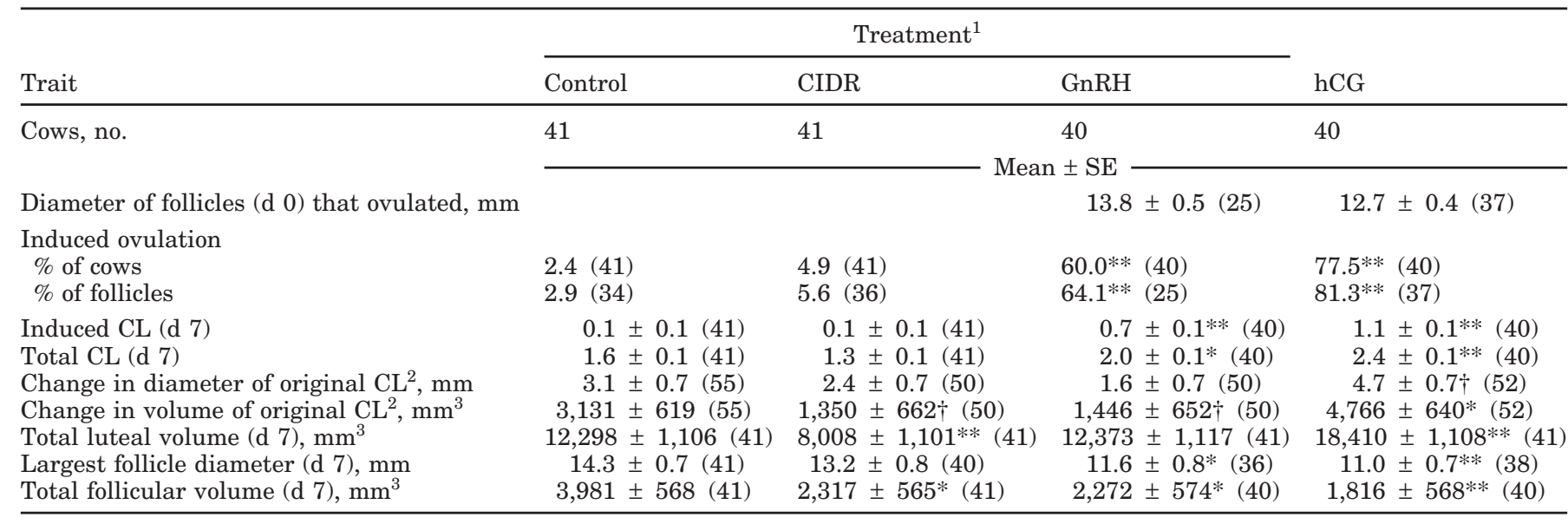

${ }^{1}$ Cows were treated once with $\mathrm{GnRH}, \mathrm{hCG}$, or a CIDR insert, beginning 4 to $9 \mathrm{~d}$ after AI. The CIDR insert was removed $7 \mathrm{~d}$ later.

${ }^{2}$ Trait assessed on $\mathrm{d} 7$ minus that on $\mathrm{d} 0$.

$\dagger$ Different $(P=0.07)$ from control; *different $(P<0.05)$ from control; **different $(P<0.01)$ from control.

CIDR inserts during $7 \mathrm{~d}$ was $94.5 \%$ of 752 cows treated with CIDR inserts. Only 711 cows in which the CIDR was retained according to protocol were included in analyses. Cows were treated after AI, which included those occurring by appointment (TAI), after visual detection of estrus, rubbed tail chalk, activity tags, and other miscellaneous signs of estrus. All cows were inseminated postpartum (first AI after calving) after presynchronization of estrous cycles and synchronization of ovulation $(\mathbf{O v}$ synch). In cows diagnosed not pregnant, ovulation was resynchronized by using Ovsynch. More than $80 \%$ of inseminations that preceded treatments in both experiments were by TAI.

\section{Experiment 1}

Ovarian characteristics of 162 treated cows (herd 1 in Table 1) are summarized in Table 2. Because a large percentage of the cows eligible for treatment at 4 to $9 \mathrm{~d}$ after AI were previously TAI, only cows that had a CL at the first ultrasound exam that was consistent in size for that stage of the estrous cycle or pregnancy were included in experiment 1 . Mean diameter of follicles just before treatment that eventually ovulated in response to GnRH or hCG did not differ. More $(P<0.01)$ cows treated with GnRH and hCG ovulated at least 1 follicle than controls. When only cows having at least 1 follicle $\geq 10 \mathrm{~mm}$ at treatment were considered, percentage of follicles that ovulated increased to 64.1 and $81.3 \%$ for GnRH and hCG cows, respectively (Table 2). Of those cows treated with GnRH and hCG that were induced to ovulate, $74.5 \%$ ovulated 1 follicle (38 of 51), whereas 2 follicles were induced to ovulate in 12 cows (23.5\%), and
3 follicles were induced to ovulate in 1 cow (2\%). Ten of the 13 cows in which more than 1 follicle was induced to ovulate were treated with hCG. In 1 control and 2 cows treated with a CIDR, a new CL was detected $7 \mathrm{~d}$ after treatment. These CL were misidentified as a follicle or were too indistinct to visualize at the initial ovarian scan.

Number of induced CL per cow and total CL per cow $7 \mathrm{~d}$ after treatment were greater $(P<0.01)$ in cows treated with GnRH and hCG than in controls (Table 2). Location of induced CL in the ovary, relative to the original CL-bearing ovary, was ipsilateral (32\%), contralateral $(41 \%)$, or both $(28 \%)$, with similar distribution patterns between $\mathrm{GnRH}$ and hCG treatments. Average numbers of induced CL per cow were $0.95 \pm 0.1,1.05 \pm$ 0.1 , and $1.5 \pm 0.1$, identified ipsilateral, contralateral, or both, relative to the original CL-bearing ovary, respectively. The relationship between number of follicles $\geq 5$ $\mathrm{mm}$ at treatment and number of induced $\mathrm{CL}$ was positive and linear $(P<0.05$; Figure 1). Cows having 4 or more follicles had more $(P<0.05)$ induced CL than did cows with 1 or 2 follicles $\geq 5 \mathrm{~mm}$ at treatment.

As expected, original CL increased in diameter and volume during $7 \mathrm{~d}$ after treatment in all cows, but changes in diameter $(P=0.07)$ and volume $(P<0.05)$ tended to be, or were, greater for cows treated with hCG than for controls. Increased CL size indicated that hCG induced hypertrophy, hyperplasia, or both in luteal cells of original CL. In contrast, change in volume of original $\mathrm{CL}$ after $7 \mathrm{~d}$ in cows from CIDR and GnRH treatments tended $(P=0.07)$ to be less than in controls. As a consequence, total luteal volume $7 \mathrm{~d}$ after treatment was less 


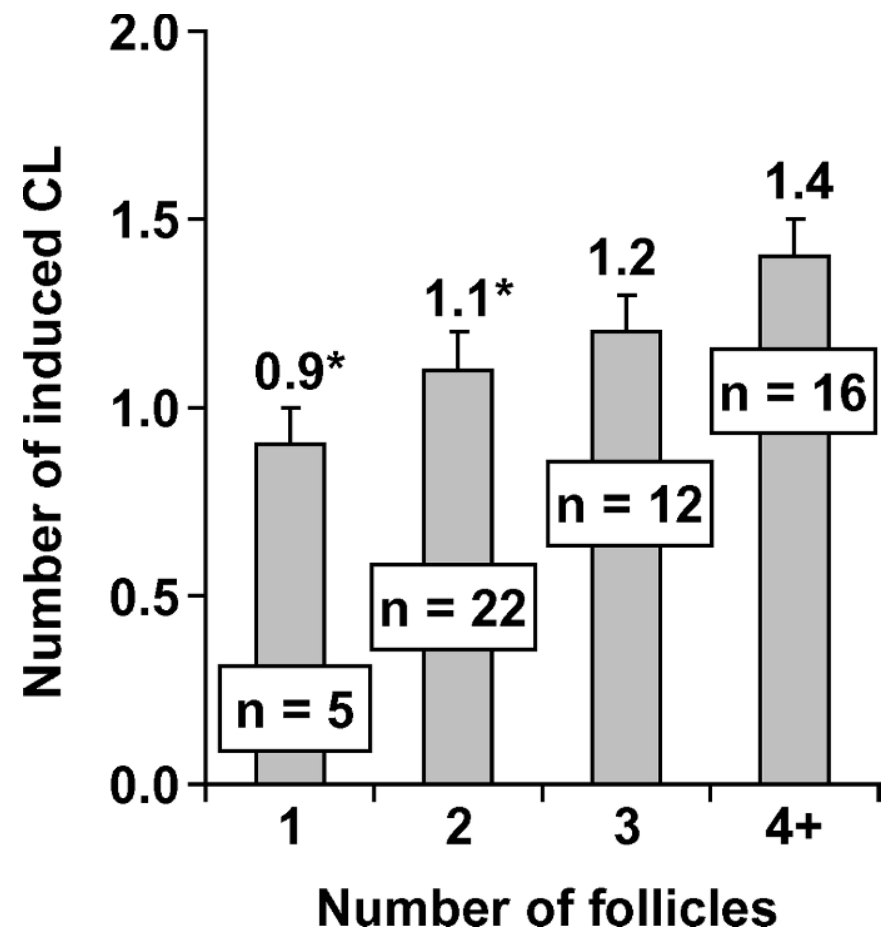

Figure 1. Linear $(P<0.05)$ relationship between the number of follicles $\geq 5 \mathrm{~mm}$ in diameter identified at the time of $\mathrm{GnRH}$ or human chorionic gonadotropin (hCG) injection and the number of induced corpus lutea (CL) identified $7 \mathrm{~d}$ later (experiment 1$)$. *Different $(P<$ 0.05) from $4+$ follicles.

$(P<0.01)$ in CIDR treatment but greater in hCG treatment compared with control (Table 2).

Because of a large incidence of induced ovulation after treatment with GnRH or hCG, diameter of the largest follicle subsequently identified in the pair of ovaries $7 \mathrm{~d}$ after treatment was less $(P \leq 0.05)$ in cows treated with GnRH and hCG than in controls. Further, mean total follicular volume $7 \mathrm{~d}$ after treatment was less $(P \leq 0.05)$ in treated cows, compared with controls (Table 2).

Concentrations of $\mathrm{P} 4$ in serum at the time of treatment and $7 \mathrm{~d}$ later were determined in 753 cows in 3 herds (herds 1, 2, and 4; Table 1). As expected, concentration of P4 in serum increased $(P<0.001)$ from day of treatment ( 4 to $9 \mathrm{~d}$ after $\mathrm{AI} ; 3.2 \pm 0.1 \mathrm{ng} / \mathrm{mL}$ ) until $7 \mathrm{~d}$ later. Increase in serum $\mathrm{P} 4$ from treatment to $7 \mathrm{~d}$ later, however, was greater $(P<0.001)$ in cows treated with hCG than in controls (Figure 2A). The second set of bars in Figure 2 represents the mean change in concentrations of $\mathrm{P} 4$ for cows in which serum P4 was $\geq 1 \mathrm{ng} / \mathrm{mL}$ at treatment and $7 \mathrm{~d}$ later. Including only cows in this analysis that met this criterion probably eliminated a large proportion of cows that were not at the appropriate stage of the estrous cycle or pregnancy at onset of treatment. Based on that criterion, change in serum P4 was consistent with the previous interpretation, in which
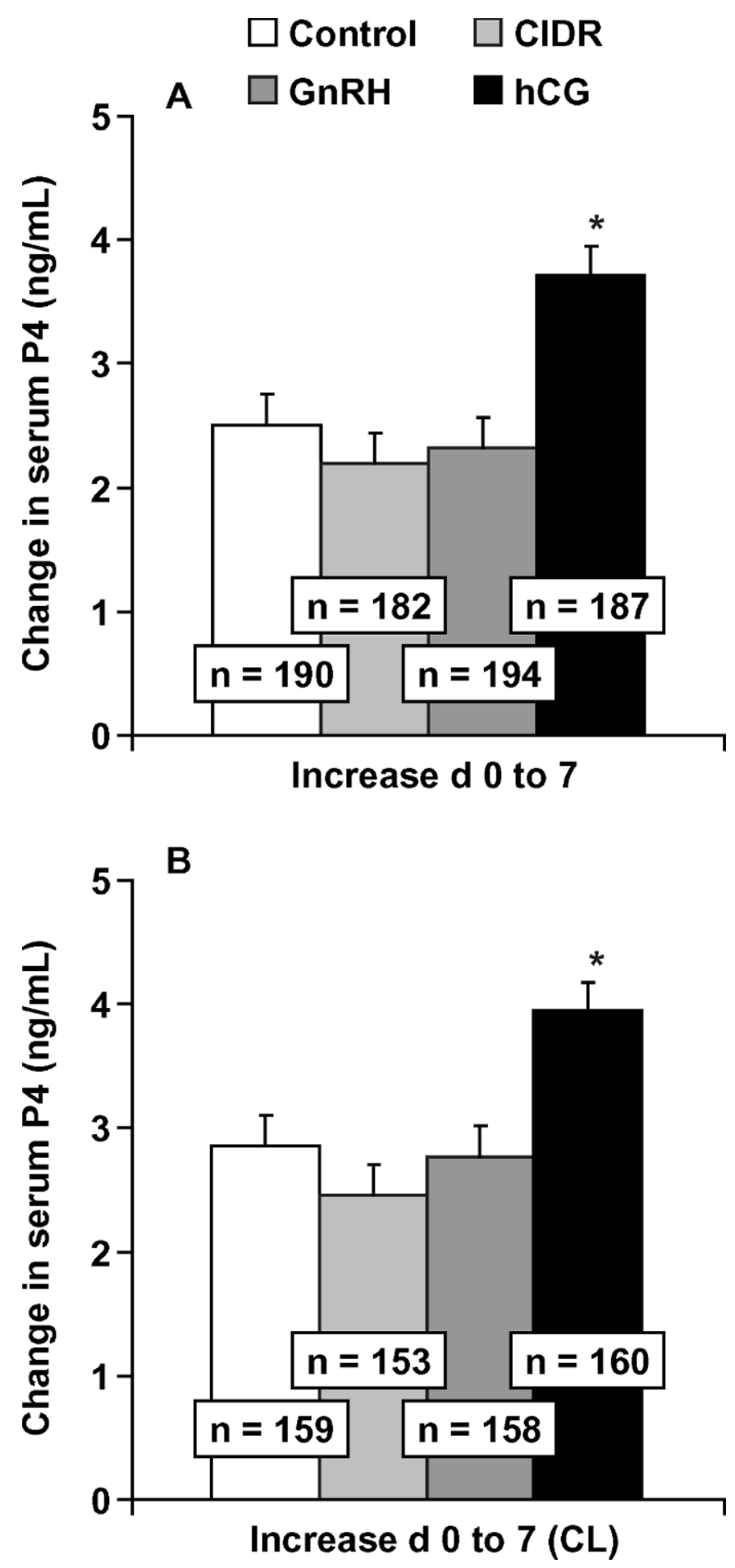

Figure 2. A. Change in concentrations of progesterone (P4) in serum between day of treatment and $7 \mathrm{~d}$ later for cows in experiment 1 . B. Change in concentrations of P4 in serum between day of treatment and $7 \mathrm{~d}$ later for those cows in experiment 1 in which serum $\mathrm{P} 4$ was $\geq 1 \mathrm{ng} / \mathrm{mL}$ at the onset of treatment and $7 \mathrm{~d}$ later, indicating cows had a functional corpus luteum (CL) at both periods. *Different $(P<0.001)$ from control. 
Table 3. Conception rates by herd in response to postinsemination treatments of progesterone [(P4) controlled internal drug release (CIDR insert)], GnRH, and human chorionic gonadotropin (hCG) in lactating dairy cows (experiment 2)

\begin{tabular}{|c|c|c|c|c|}
\hline \multirow[b]{2}{*}{ Herd } & \multicolumn{4}{|c|}{ Treatment $^{1}$} \\
\hline & Control & CIDR & GnRH & hCG \\
\hline & & $\%$ & & \\
\hline 1 & $31.7(41)$ & $50.1 \dagger(40)$ & $32.6(40)$ & $38.7(38)$ \\
\hline 2 & $26.0(158)$ & $30.8(158)$ & $28.6(159)$ & $34.0(158)$ \\
\hline 3 & 26.9 (143) & $40.3^{* *}(162)$ & 31.3 (153) & $37.8^{*}(153)$ \\
\hline 4 & $33.8(206)$ & $23.4^{*}(204)$ & 29.8 (209) & 33.7 (209) \\
\hline 5 & $23.8(160)$ & 22.3 (147) & $20.2(158)$ & 25.6 (156) \\
\hline Total $^{2}$ & $28.3(708)$ & $32.7(711)$ & $28.1(719)$ & $33.6(714)$ \\
\hline
\end{tabular}

${ }^{1}$ Cows were treated with once $\mathrm{GnRH}, \mathrm{hCG}$, or a CIDR insert, beginning 4 to $9 \mathrm{~d}$ after AI. The CIDR insert was removed $7 \mathrm{~d}$ later.

${ }^{2} \mathrm{~A}$ tendency $(P=0.11)$ for a treatment $\times$ herd interaction. Adjusted a priori contrasts: CIDR vs. control $(P=0.075)$ and hCG vs. control $(P<0.05)$.

$\dagger, *, * *$ Different from control within herd based on unadjusted $\chi^{2}$ at $\dagger P<0.10,{ }^{*} P<0.05$, and ${ }^{* *} P<0.01$.

only hCG caused a greater $(P<0.001)$ increase in $\mathrm{P} 4$ than controls (Figure 2B).

Of the total cows sampled in herds 2 and 4, the proportion in which serum $\mathrm{P} 4$ was $\geq 1 \mathrm{ng} / \mathrm{mL}$ at treatment and $7 \mathrm{~d}$ later was 481 of 594 (81\%). A comparable proportion of cows in herd 1, which were known to be properly staged because each cow treated had a CL verified by ultrasonography, was 150 of 162 cows (92.6\%). Difference in these 2 proportions indicates that approximately $12 \%$ of the cows in herds 2 and 4 may not have been treated at the designed postinsemination interval.

The partial correlation between follicle diameters identified on $\mathrm{d} 0$ and subsequent diameter of the induced CL forming from that follicle was $0.54(P<0.001)$. A smaller correlation was detected between follicle volume and induced CL volume $(\mathrm{r}=0.33 ; P<0.001)$. Relative to total luteal volume (all CL identified on d 7) in controls of herd 1, proportion of total luteal volume was 65.1, 100.6, and $149.7 \%$ for CIDR, GnRH, and hCG treatments, respectively. Similar proportions, relative to concentration of serum P4 in controls on d 7, were 97.4, 84.8 , and $109.4 \%$, respectively. The preceding proportions partly explain why the partial correlation between serum $\mathrm{P} 4$ concentrations on $\mathrm{d} 7$ and total luteal volume was small $(\mathrm{r}=0.15 ; P=0.07)$.

\section{Experiment 2}

Conception rates of 2,852 cows in 5 herds described in Tables 3 and 4 were assessed by ultrasonography in 2 herds (herds 1 and 3 ) and by palpation per rectum of uterine contents in 3 herds (herds 2 , 4 , and 5). Treatment with hCG increased $(P<0.05)$ conception rates in herd
3. Treatment with hCG increased $(P<0.01)$ conception rates in second-lactation cows (Table 4). Overall, a priori contrasts indicated that the CIDR tended $(P=0.075)$ to increase and hCG increased $(P<0.05)$ conception rates compared with controls (Table 3 ).

Conception rates were influenced by herd; rates were greater $(P<0.05)$ in 2 herds (herd $1=38.9 \%$ and herd $3=36.6 \%$ ) in which pregnancy was diagnosed earlier after AI, compared with the 3 herds in which pregnancy was determined later by palpation (herd $2=30.9 \%$, herd $4=29.3 \%$, and herd $5=23.9 \%)$. Month of treatment $(P$ $<0.05)$, DIM $(P<0.001)$, BCS $(P<0.001)$, and number of days after AI when treatment was initiated $(P<0.05)$ influenced conception rates, whereas most recent testday milk yield had no effect. Average day effects across herds indicated that when treatment occurred after $\mathrm{d} 6$, conception rates increased $(\mathrm{d} 4=26.6 \%, \mathrm{~d} 5=27.6 \%$, d $6=26.2 \%$, d $7=34.1 \%$, d $8=32.5 \%$, and d $9=44.5 \%$; no treatment $\times$ day interaction). Conception rates in response to treatments based on day after AI when treatment was initiated are illustrated in Figure 3.

Regression coefficient for DIM was negative and indicated that conception rate decreased $(P<0.001) 6.4 \pm$ $1.7 \%$ for every 100 -d increase in DIM at treatment. In contrast, the regression coefficient for BCS was positive and indicated that cows having greater $(P<0.001) \mathrm{BCS}$ were more fertile ( $11.5 \pm 2.3 \%$ per unit increase in BCS).

Pregnancy survival is summarized in Table 4. Survival was reduced $(P<0.05)$ by GnRH in cows in their third or greater lactation, compared with contemporary controls in the same lactation group. A priori contrasts indicated that pregnancy survival tended $(P=0.09)$ to be slightly reduced by hCG treatment and was reduced $(P=0.05)$ by $\mathrm{GnRH}$ treatment. As expected, pregnancy survival was less $(P<0.01)$ in the 2 herds (herd $1=$ $89.4 \%$ and herd $3=91.6 \%$ ) in which pregnancy was diagnosed earlier after AI, compared with the 3 herds in which pregnancy was confirmed later by palpation (herd $2=100 \%$, herd $4=97.4 \%$, and herd $5=97.8 \%$ ). None of the other independent variables in the model significantly influenced pregnancy survival, including the most recent test-day milk yield, DIM, or BCS, except a tendency $(P=0.10)$ for month of treatment.

\section{DISCUSSION}

Cows in our study were treated once between 4 and $9 \mathrm{~d}$ after AI, concomitant with the rise of the first-wave dominant follicle in lactating dairy cows (Lucy et al., 1992). As expected, a large proportion of dominant follicles ovulated in response to $\mathrm{GnRH}(64.1 \%)$ or hCG (81.3\%). Proportions of induced CL at this stage of the estrous cycle or pregnancy are consistent with other re- 
Table 4. Conception rates and pregnancy survival by lactation group in response to postinsemination treatments of progesterone [(P4) controlled internal drug release (CIDR insert)], GnRH, and human chorionic gonadotropin (hCG) in lactating dairy cows (experiment 2)

\begin{tabular}{|c|c|c|c|c|}
\hline \multirow[b]{2}{*}{ Lactation number } & \multicolumn{4}{|c|}{ Treatment $^{1}$} \\
\hline & Control & CIDR & GnRH & $\mathrm{hCG}$ \\
\hline & & & & \\
\hline \multicolumn{5}{|l|}{ Conception rates } \\
\hline First & $32.8(246)$ & $34.9(252)$ & $36.0(249)$ & $33.2(250)$ \\
\hline Second & $26.0(204)$ & $34.0(203)$ & $27.1(208)$ & $39.6^{* *}(208)$ \\
\hline Third+ & $26.5(258)$ & $31.2(256)$ & $22.3(262)$ & $29.1(256)$ \\
\hline \multicolumn{5}{|l|}{ Pregnancy survival ${ }^{2}$} \\
\hline First & $99.2(84)$ & $96.6(84)$ & $95.7(88)$ & $95.7(79)$ \\
\hline Second & $97.7(48)$ & $93.1(54)$ & $95.6(48)$ & $93.2(75)$ \\
\hline Third+ & $95.0(66)$ & $89.6(72)$ & $85.5^{*}(58)$ & $98.3(73)$ \\
\hline Total $^{2}$ & $97.3(198)$ & $93.1(210)$ & $92.2(194)$ & $95.7(227)$ \\
\hline \multicolumn{5}{|c|}{$\begin{array}{l}{ }^{1} \text { Cows were treated once with GnRH, hCG, or a CIDR insert, beginning } 4 \text { to } 9 \mathrm{~d} \text { after AI. The CIDR insert } \\
\text { Nas removed } 7 \mathrm{~d} \text { later. }\end{array}$} \\
\hline \multicolumn{5}{|c|}{$\begin{array}{l}{ }^{2} \mathrm{~A} \text { tendency }(P=0.07) \text { for a treatment } \times \text { lactation number interaction. Adjusted a priori contrasts: CIDR } \\
\text { vs. control }(P=0.11) \text { and GnRH vs. control }(P=0.07) \text {. }\end{array}$} \\
\hline \multicolumn{5}{|c|}{$\begin{array}{l}* \text { Different }(P<0.05) \text { from control within lactation number based on unadjusted } \chi^{2} \text {; ** different }(P<0.01) \\
\text { from control within lactation number based on unadjusted } \chi^{2} \text {. }\end{array}$} \\
\hline
\end{tabular}

ports for GnRH (Vasconcelos et al., 1999) and hCG (Fricke et al., 1993; Santos et al., 2001).

Greater growth of the original CL in response to hCG is consistent with the fact that hCG has activity similar to LH. Human chorionic gonadotropin is able to bind to target tissue $\mathrm{LH}$ receptors and mimic the effects of $\mathrm{LH}$ by causing small luteal cells to increase P4 synthesis. Number of small luteal cells increased approximately 5- fold from d 4 to 16 of the untreated ovine estrous cycle, with little change in cell volume, whereas large luteal cells increased in size, with little change in cell number (Niswender et al., 2000). We interpret the increase in the original CL diameter and volume in response to hCG to have resulted from changes in luteal cell populations and proportions as reported in the ovine. When given early in the ovine estrous cycle (d 3 to 5), hCG altered

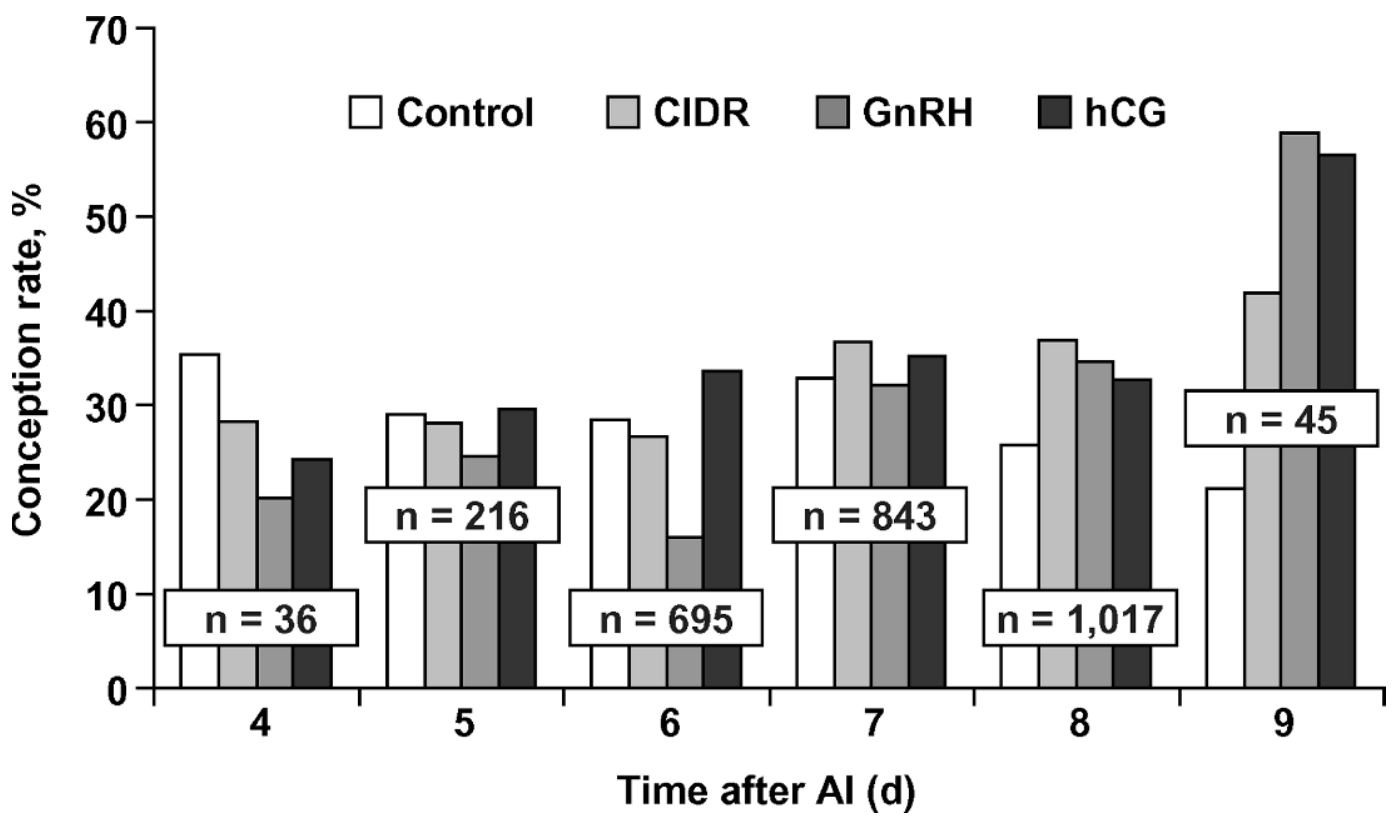

Figure 3. Conception rates of lactating dairy cows treated once with GnRH, human chorionic gonadotropin (hCG), or a controlled internal drug release $($ CIDR) for $7 \mathrm{~d}$, compared with controls, based on day after AI when treatment was initiated. Day influenced $(P<0.05)$ conception rates, but no treatment $\times$ day interaction was detected $(P=0.47)$. 
the proportion of small and large luteal cells, thus potentially changing total production of $\mathrm{P} 4$ by the CL because approximately $80 \%$ of luteal $\mathrm{P} 4$ is derived from large luteal cells (Niswender et al., 2000). Increased blood P4 can occur because of the effects of hCG on the existing CL or by stimulating the formation of accessory CL (Fricke et al., 1993; Schmitt et al., 1996; Santos et al., 2001). Although greater concentrations of P4 in serum were detected in hCG-treated cows in our study, the percentage increase in total luteal volume (including original and accessory CL) in response to hCG (50\%) was greater than the percentage increase in serum P4 (9\%), compared with controls. Corpora lutea induced by hCG on d 6 of the cycle differed in color and size from the original CL and, when cultured with $\mathrm{LH}$, produced less P4 in vitro than was produced by spontaneously formed CL of comparable age (Fricke et al., 1993).

Inducing accessory $\mathrm{CL}$ with $\mathrm{GnRH}$ or its agonists is well documented and forms the basis for the first injection in the Ovsynch protocol (Pursley et al., 1998). In the present study, $100 \mu \mathrm{g}$ of GnRH did not increase total luteal volume or serum P4 concentrations by d 7 after treatment, which is consistent with results of Sterry et al. (2006). In contrast, in lactating dairy cows treated with $100 \mu \mathrm{g}$ of $\mathrm{GnRH}$ on d 5 after AI, serum P4 was greater on d 14 in 12 of 12 cows in which accessory CL were induced (Howard et al., 2006).

Although in our study GnRH seemed slightly less effective in inducing accessory CL than was hCG, a GnRH agonist (Buserelin) was equally as effective as 3,000 IU of hCG for inducing accessory CL when injected on d 5 or 6 of the cycle, but subsequent increases in concentrations of P4 were greater in hCG-treated heifers (Schmitt et al., 1996). The same dose of Buserelin, given to lactating nonpregnant or pregnant dairy cows 11 to $14 \mathrm{~d}$ after estrus and AI, increased serum P4 beginning $3 \mathrm{~d}$ after injection, and serum $\mathrm{P} 4$ remained greater than controls for up to 3 and $12 \mathrm{~d}$, respectively (Stevenson et al., 1993). Likewise, when $100 \mu \mathrm{g}$ of GnRH was given to lactating dairy cows at $12 \mathrm{~h}$ after the onset of estrus, luteal slices from their CL removed $10 \mathrm{~d}$ later produced more P4 in the presence of $\mathrm{LH}$ than did comparable luteal slices removed from control cows treated at estrus with saline (Mee et al., 1993). Further, CL from those GnRH-treated cows had a greater proportion of large luteal cells and a lesser proportion of small luteal cells. It seems that timing of administration, potency of GnRH, or both, may determine ability of GnRH to alter luteal composition and subsequent serum concentrations of P4.

Treatment of cows with CIDR inserts in the present study failed to increase concentrations of $\mathrm{P} 4$ in serum. Studies conducted to administer exogenous progestins during the luteal phase after insemination by applying the PRID for 6 to $12 \mathrm{~d}$ produced inconsistent effects on serum P4 (Robinson et al., 1989; Stevenson and Mee, 1991). Concentrations of $\mathrm{P} 4$ in the former study were increased when cows were treated with a PRID for $7 \mathrm{~d}$ between $\mathrm{d} 5$ and 12 , but not when treated between $\mathrm{d} 12$ and 19. In other studies, CIDR inserts placed in cows during the luteal phase increased serum concentrations of P4 by only 0.5 to $1 \mathrm{ng} / \mathrm{mL}$ (Stevenson et al., 2003; Sterry et al., 2006; Stevenson et al., 2006).

Although all cows were treated once between 4 and 9 $\mathrm{d}$ after AI, serum $\mathrm{P} 4$ concentrations indicate that approximately $12 \%$ of cows may not have been treated between 4 to $9 \mathrm{~d}$ after estrus. Because a large percentage of cows were treated after a TAI, only the study conducted in herd 1 (experiment 1) was a true biological test of the treatments relative to days after estrus. In that herd, the CIDR insert tended to improve conception rates in a limited number of cows $(\mathrm{n}=40)$ per treatment, in addition to positive conception results observed in herd 3 . Percentage of cows that was properly staged (89\%) is consistent with reported synchronization rates (proportion of cows in which concentrations of $\mathrm{P} 4$ at $48 \mathrm{~h}$ after $\mathrm{PGF}_{2 \alpha}$ injection in an TAI protocol were similar to those found in estrual cows) in other studies (Pursley et al., 1998; Stevenson et al., 2006).

Conception rates in our study revealed a tendency for interactions of treatment with herd $(P=0.11)$ and lactation number $(P=0.07)$. Although more than 700 cows were enrolled per treatment, use of the CIDR only tended to improve conception rates, whereas hCG significantly improved conception rates. When the CIDR was used, in 2 of 5 herds tested (based on $\chi^{2}$ tests), the CIDR improved conception rates (in 1 herd the increase was significant), whereas in 2 herds, conception rates were less than in controls (in 1 herd the decrease was significant). Although the CIDR may have improved conception rates, it seemed to do so without elevating peripheral concentrations of $\mathrm{P} 4$. Conception success is coincident with normal concentrations of P4 as early as d 6 after insemination, and timing and magnitude of the P4 increase generally occur earlier and reach greater concentrations in pregnant than in nonpregnant cows (Thatcher et al., 2001). Embryo development is related to concentrations of $\mathrm{P} 4$ and the ability of the conceptus to secrete the antiluteolytic hormone, interferon- $\tau$ (Mann et al., 1999). Exogenous P4 stimulates embryo development (Thatcher et al., 1994).

In the present study, although more than $60 \%$ of the monitored cows formed accessory CL in response to treatment with GnRH once between 4 and $9 \mathrm{~d}$ after AI, GnRH did not increase conception rates. Failure to improve conception rates is consistent with results of another recent study in which dairy cows were treated on d 5 after estrus and AI (Howard et al., 2006). Results of a meta-analysis (Peters et al., 2000) in which cows 
were treated with GnRH from 11 to $14 \mathrm{~d}$ after AI, showed that fertility was improved in only 5 of 19 studies; when the analysis was limited to 6 studies having 5 common variables, however, GnRH treatment improved conception rates. Timing of treatment after estrus may be a critical component of the potential for $\mathrm{GnRH}$ to improve conception potential.

Not all studies reported improved conception rates in cattle when they were treated with hCG at various periods after AI. Conception rates in beef heifers were improved when hCG was administered on d 4 after estrus (Breuel et al., 1989) and on d 5 after AI in lactating dairy cows (Santos et al., 2001), but in at least 8 other studies, no positive effect was detected in cattle when hCG was administered in various regimens between 3 and $35 \mathrm{~d}$ after estrus (Rettmer, 1991). Treatment with hCG in the present study significantly improved conception rate in 1 herd and increased conception rates in second-lactation cows. Treatment success is likely related to the timing of the hCG treatment after AI and the stage of follicle maturity because lactating dairy cows treated with 1,000 IU of hCG on d 0, 7, or 14 after estrus had greater rates of accessory CL formation on d 0 (3 of 8 cows); 7 ( 7 of 9 cows), and d 14 (4 of 9 cows), compared with 1 of 8 nontreated controls (Rajamahendran and Sianangama, 1992).

Overall, a significant effect of day of treatment initiation was detected in our study. Treatments with the CIDR, GnRH, and hCG initiated after d 6 consistently improved fertility compared with control. This timing is consistent with the conclusions of Macmillan and Peterson (1993) who used the CIDR. When treatments were initiated before midcycle, conception rates were improved for cows treated with CIDR inserts for 6 or $12 \mathrm{~d}$, beginning 4 to $9 \mathrm{~d}$ after AI. The most consistent treatment, resulting in best conception rates used 7-d treatments beginning on $\mathrm{d} 6$ to 8 after AI. Conclusions of the previous study are consistent with a meta-analysis of $17 \mathrm{P} 4$ supplementation studies, in which treatment during the first week of pregnancy increased conception rates but provided no benefit when administered during the second and third weeks of pregnancy (Mann and Lamming, 1999).

Embryonic mortality after conception is a significant contributor to reduced conception rates in lactating dairy cattle, and growing evidence for this assertion was summarized recently (Santos et al., 2004). We had anticipated that embryo survival might improve in response to treatments in which serum P4 was increased. Because pregnancy survival was not improved between the first and second pregnancy diagnoses and improvements tended to occur in initial conception rates, only very early embryo loss was spared in CIDR and hCG cows before the first pregnancy diagnosis. Most embryo deaths occur early after fertilization (Santos et al., 2004), with $30 \%$ by $\mathrm{d} 7,40 \%$ between $\mathrm{d} 8$ and 17 , and $24 \%$ between $\mathrm{d} 17$ and 24 after AI. Timing of our treatments may have reduced pregnancy loss in any of these periods but most likely reduced losses before maternal recognition of pregnancy (d 14 to 17). Early embryo growth and development is stimulated by P4 (Thatcher et al., 2001), and serum P4 and conception were increased by hCG. In contrast, effects of the CIDR were not reflected by increases in serum P4. Despite this lack of increase in peripheral concentrations of $\mathrm{P} 4$, physiological effects on the uterus and embryo may have occurred.

Application of microionized $\mathrm{P} 4$ via the vagina doubled concentrations of $\mathrm{P} 4$ in uterine arterial blood in human females, compared with concentrations of $\mathrm{P} 4$ in peripheral arterial blood (Cicinelli et al., 2000). Further, concentrations of $\mathrm{P} 4$ in endometrial cells were 10 to 20 times greater after vaginal administration than after i.m. injections of $\mathrm{P} 4$ given in doses resulting in identical peripheral concentrations of $\mathrm{P} 4$. Results of that experiment indicate that the uterus and the embryo may be influenced by vaginal treatment with $\mathrm{P} 4$, even though peripheral concentrations of $\mathrm{P} 4$ were not elevated or were only slightly elevated.

Because the CIDR may have increased local, but not peripheral, concentrations of $\mathrm{P} 4$ in other reproductive tissues, and hCG increased peripheral concentrations of P4, it would be logical to speculate that improved fertility was a direct effect of $\mathrm{P} 4$. Although $\mathrm{GnRH}$ and hCG were effective ( $>60 \%)$ in inducing ovulation of ancillary CL, serum P4 was only elevated in the hCG-treated cows. In contrast, potential improvements in fertility were evident in hCG-treated cows, and in CIDR-treated cows, for which no increase in serum P4 was detected. Cows treated with GnRH probably had elevated serum P4 after d 7 (Howard et al., 2006), but in that study and in the present study, no fertility response was observed. This indicates that the positive effect of hCG on fertility may be independent of elevated serum concentrations of P4. If true, the mechanism whereby fertility was enhanced independent of elevated serum concentrations of P4 is unknown.

\section{CONCLUSIONS}

Treatment of lactating dairy cows once with GnRH and hCG between 4 and $9 \mathrm{~d}$ after AI effectively induced ovulation and increased number of CL (not total CL volume after $\mathrm{GnRH}$ ) but only increased serum $\mathrm{P} 4$ in hCG-treated cows. Further, treatment with the CIDR tended to increase, and treatment with hCG increased conception rates, but only in some herds. Treatment of second-lactation cows with hCG increased conception rates. Further work is warranted to determine how and 
when vaginally applied $\mathrm{P} 4$ via the CIDR may influence conception rates.

\section{ACKNOWLEDGMENTS}

We express appreciation to owners and employees at Ohlde's Dairy, Linn, KS; Meier's Dairy, Palmer, KS; Linn Willow Creek Dairy, Linn, KS; and York's Dairy, Cuba City, WI; for their willingness to cooperate in this study. We acknowledge the financial support for these studies provided by the National Association of Animal Breeders, Columbia, MO. We thank the dairy staff at the Kansas State University Dairy Teaching and Research Center for their assistance in conducting this study. We thank Irene Vanderwerff for her laboratory assistance.

\section{REFERENCES}

Breuel, K. F., J. C. Spitzer, and D. M. Henricks. 1989. Systemic progesterone concentration following human chorionic gonadotropin administration at various times during the estrous cycle in beef heifers. J. Anim. Sci. 67:1564-1572.

Cicinelli, E., D. de Ziegler, C. Bulletti, M. G. Matteo, L. M. Schonauer, and P. Galantino. 2000. Direct transport of progesterone from vagina to uterus. Obstet. Gynecol. 95:403-406.

Eduvie, L. O., and B. E. Seguin. 1982. Corpus luteum function and pregnancy rate in lactating dairy cows given human chorionic gonadotropin at middiestrus. Theriogenology 17:415-422.

Fricke, P. M., L. P. Reynolds, and D. A. Redmer. 1993. Effect of human chorionic gonadotropin administered early in the estrous cycle on ovulation and subsequent luteal function in cows. J. Anim. Sci. $71: 1242-1246$.

Howard, H. J., and J. H. Britt. 1990. Prostaglandin $\mathrm{F}_{2 \alpha}$ causes regression of an hCG-induced corpus luteum before day 5 of its life-span in cattle. J. Reprod. Fertil. 90:245-253.

Howard, J. M., R. Manzo, J. C. Dalton, F. Frago, and A. Ahmadzadeh. 2006. Conception rates and serum progesterone concentration in dairy cattle administered gonadotropin releasing hormone 5 days after artificial insemination. Anim. Reprod. Sci. 95:224-233.

Lucy, M. C., J. D. Savio, L. Badinga, R. L. de la Sota, and W. W. Thatcher. 1992. Factors that affect ovarian follicular dynamics in cattle. J. Anim. Sci. 70:3615-3626.

Macmillan, K. L., and A. J. Peterson. 1993. A new intravaginal progesterone releasing device for cattle (CIDR-B) for oestrous synchronisation, increasing pregnancy rates and the treatment of postpartum anoestrus. Anim. Reprod. Sci. 33:1-25.

Mann, G. E., and G. E. Lamming. 1999. The influence of progesterone during early pregnancy in cattle. Reprod. Domest. Anim. 34:269-274.

Mann, G. E., G. E. Lamming, R. S. Robinson, and D. C. Wathes. 1999. The regulation of interferon-J production and uterine hormone receptors during early pregnancy. J. Reprod. Fertil. 54(Suppl. 1):317-328.

Mee, M. O., J. S. Stevenson, R. G. Sasser, and B. M. Alexander. 1993. Administration of $\mathrm{GnRH}$ at estrus influences pregnancy rates, serum concentrations of LH, FSH, estradiol-17 $\beta$, pregnancy-specific protein $\mathrm{B}$, and progesterone, proportion of luteal cells, and in vitro production of progesterone in dairy cows. J. Anim. Sci. 71:185-198.

Niswender, G. D., J. L. Juengel, W. J. McGuire, P. J. Silva, M. K. Rollyson, and E. W. McIntush. 2000. Mechanisms controlling the function and life span of the corpus luteum. Physiol. Rev. 80:2-29.
Peters, A. R., T. A. Martinez, and A. J. Cook. 2000. A meta-analysis of the effect of GnRH 11-14 days after insemination on pregnancy rates in cattle. Theriogenology 54:1317-1326.

Pursley, J. R., R. W. Silcox, and M. C. Wiltbank. 1998. Effect of time of artificial insemination of pregnancy rates, calving rates, pregnancy loss, and gender ratio after synchronization of ovulation in lactating dairy cows. J. Dairy Sci. 81:2139-2144.

Rajamahendran, R., and P. C. Sianangama. 1992. Effect of human chorionic gonadotropin on dominant follicles in cows: Formation of accessory corpora lutea, progesterone production and pregnancy rates. J. Reprod. Fertil. 95:577-584.

Rettmer, I. 1991. Administration of a GnRH analog agonist (fertirelin acetate) during the mid-luteal phase of the estrous cycle: Effects on pregnancy rates, hormonal profiles and ovarian follicular and luteal dynamics. MS Thesis, Kansas State Univ., Manhattan.

Robinson, N. A., K. E. Leslie, and J. S. Walton. 1989. Effect of treatment with progesterone on pregnancy rate and plasma concentrations of progesterone in Holstein cows. J. Dairy Sci. 72:202-207.

Santos, J. E., W. W. Thatcher, R. C. Chebel, R. L. Cerri, and K. N. Galva. 2004. The effect of embryonic death rates in cattle on the efficacy of estrus synchronization programs. Anim. Reprod. Sci. 82-83:513-535.

Santos, J. E. P., W. W. Thatcher, L. Pool, and M. W. Overton. 2001. Effect of human chorionic gonadotropin on luteal function and reproductive performance of high-producing lactating Holstein dairy cows. J. Anim. Sci. 79:2881-2894.

Schmitt, E. J. P., T. Diaz, C. M. Barros, R. L. de la Sota, M. Drost, E. W. Fredriksson, C. R. Staples, R. Thorner, and W. W. Thatcher. 1996. Differential response of the luteal phase and fertility in cattle following ovulation of the first-wave follicle with human chorionic gonadotropin or an agonist of gonadotropin-releasing hormone. J. Anim. Sci. 74:1074-1083.

Skaggs, C. L., B. V. Able, and J. S. Stevenson. 1986. Pulsatile or continuous infusion of luteinizing hormone releasing hormone and hormonal concentrations in prepubertal beef heifers. J. Anim. Sci. 62:1034-1048.

Sterry, R. A., M. L. Welle, and P. M. Fricke. 2006. Treatment with gonadotropin-releasing hormone after first timed artificial insemination improves fertility in noncycling lactating dairy cows. J. Dairy Sci. 89:4237-4245.

Stevenson, J. S., G. C. Lamb, S. K. Johnson, M. A. Medina-Britos, D. M. Grieger, K. R. Harmoney, J. A. Cartmill, S. Z. El-Zarkouny, C. R. Dahlen, and T. J. Marple. 2003. Supplemental norgestomet, progesterone, or melengestrol acetate increases pregnancy rates in suckled beef cows after timed inseminations. J. Anim. Sci. 81:571-586.

Stevenson, J. S., and M. O. Mee. 1991. Pregnancy rates of Holstein cows after postinsemination treatment with a progesterone-releasing intravaginal device. J. Dairy Sci. 74:3849-3856.

Stevenson, J. S., A. P. Phatak, I. Rettmer, and R. E. Stewart. 1993. Postinsemination administration of receptal: Follicular dynamics, duration of cycle, hormonal responses, and pregnancy rates. J. Dairy Sci. 76:2536-2547.

Stevenson, J. S., J. R. Pursley, H. A. Garverick, P. M. Fricke, D. J. Kesler, J. S. Ottobre, and M. C. Wiltbank. 2006. Treatment of cycling and noncycling lactating dairy cows with progesterone during Ovsynch. J. Dairy Sci. 89:2567-2578.

Thatcher, W. W., F. Moreira, J. E. P. Santos, R. C. Mattos, F. L. Lopes, S. M. Pancarci, and C. A. Risco. 2001. Effects of hormonal treatments on reproductive performance and embryo production. Theriogenology 55:75-89.

Thatcher, W. W., C. R. Staples, G. Danet-Desnoyers, G. Oldick, and E.-P. Schmidt. 1994. Embryo health and mortality in sheep and cattle. J. Anim. Sci. 72:16-30.

Vasconcelos, J. L. M., R. W. Silcox, G. J. M. Rosa, J. R. Pursley, and M. C. Wiltbank. 1999. Synchronization rate, size of the ovulatory follicle, and pregnancy rate after synchronization of ovulation beginning on different days of the estrous cycle in lactating dairy cows. Theriogenology 52:1067-1078. 